\title{
Surface Characterization of Virulent Treponema pallidum
}

\author{
JOHN F. ALDERETE $\dagger$ AND JOEL B. BASEMAN $\dagger^{*}$ \\ Department of Bacteriology and Immunology, University of North Carolina School of Medicine, Chapel \\ Hill, North Carolina 27514
}

\begin{abstract}
Characterization of the surface of Treponema pallidum was accomplished by $\left[{ }^{125} \mathrm{I}\right]$ lactoperoxidase-catalyzed iodination of intact organisms and sensitive radioimmunoprecipitation and gel electrophoresis technology. At least 11 outer membrane proteins with molecular weights ranging from $89,000(89 \mathrm{~K})$ to $20 \mathrm{~K}$ were identified, and all elicited high titers of antibody in experimentally infected rabbits. Proteins of $89.5 \mathrm{~K}, 29.5 \mathrm{~K}$, and $25.5 \mathrm{~K}$ previously implicated as ligands involved in attachment (J. B. Baseman and E. C. Hayes, J. Exp. Med. 151:573586,1980 ) were found to reside on the treponemal surface. Low levels of the $89.5 \mathrm{~K}$ treponemal protein were released by high salt concentrations, whereas the remaining comigrating material was neither radioiodinated nor released with selective detergents. Other lower-molecular-weight $(60 \mathrm{~K}, 45 \mathrm{~K}$, and $30 \mathrm{~K})$ surface proteins were extracted with octyl glucoside detergent, suggesting their hydrophobic interaction with the external membrane. The molecular organization of surface proteins was studied by employing the cross-linker dithiobis(succinimidyl)propionate, and data suggested the presence of a highly fluid envelope resulting in random collisions by the surface proteins. The biological function of the treponemal outer envelope proteins was evaluated using, as the indicator system, adherence of $T$. pallidum to monolayer cultures of eucaryotic cells. Trypsin treatment of motile, freshly harvested organisms decreased the extent of surface parasitism to normal rabbit testicular cells, reinforcing the idea of the proteinaceous nature and role of treponemal ligands for attachment. Other data supported functional and antigenic relatedness among the implicated ligands. Finally, brief periodate treatment of human epithelial (HEp-2) and normal rat testicular cells as well as casein-elicited rabbit peritoneal macrophages significantly reduced the extent of treponemal parasitism, suggesting a role of specific host membrane molecules as mediators of attachment.
\end{abstract}

Despite the extensive literature describing the complex interrelationship between Treponema pallidum, the causative agent of syphilis, and host cells $(3,5,8,11-14,17,23,41)$, little information exists concerning the molecular and chemical characterization of the treponemal surface $(20,21)$. One reason for this deficiency is the failure to cultivate large numbers of organisms in vitro $(11-14,17,23,41)$; therefore, sufficient amounts of treponemal material necessary for purification of the outer membrane and isolation of key antigens are not available. Because of these problems in $T$. pallidum research, new molecular approaches must be utilized for the identification of surface virulence determinants as they relate to disease pathogenesis.

Of interest are the nature and polarity of attachment of $T$. pallidum to the membranes of eucaryotic cells (17). Recently, specific treponemal proteins have been implicated as ligands responsible for the surface parasitism (3). Additionally, molecular analysis of the humoral im-

† Present address: Department of Microbiology, University of Texas Health Science Center, San Antonio, TX 78284. mune response in infected experimental animals (J. F. Alderete and J. B. Baseman, submitted for publication) and humans (3) using radioimmunoprecipitation (RIP) methodology demonstrated the highly antigenic nature of these putative ligands as well as other treponemal proteins. Our approach in defining biologically relevant treponemal antigens is to investigate possible structure-function relationships of outer membrane proteinaceous components of $T$. pallidum.

The elucidation of surface macromolecules with specific biological functions, such as mediating host cell surface parasitism $(10,19,36)$, is essential to the generation of rational vaccine candidates to prevent or limit disease progression. Likewise, characterization of the outer membrane of T. pallidum in a manner analogous to other parasite systems $(15,22,25,29,33)$ is prerequisite for future studies dealing with ligand-receptor interactions as well as understanding the parasite's ability to evade immune surveillance $(32,33)$. We have, therefore, attempted to analyze the treponemal surface and 
demonstrate the highly immunogenic nature of certain prominent antigens. These results reinforce our previous findings on the importance of specific $T$. pallidum outer envelope proteins as virulence determinants $(3,5,17)$.

\section{MATERIALS AND METHODS}

Bacteria. T. pallidum (Nichols) organisms were preserved in the presence of $10 \%$ dimethyl sulfoxide in liquid nitrogen (35) before intratesticular inoculation of New Zealand white male rabbits as described elsewhere $(1,4$; Alderete and Baseman, submitted for publication). Treponemes were harvested from minced tissue by using an extraction medium containing a salts-glucose-pyruvate mixture and reducing agents (1), and approximately $1 \times 10^{8}$ to $3 \times 10^{8}$ treponemes per $\mathrm{ml}$ of medium were separated from host cellular contamination by two sequential centrifugations at $500 \times g$ for $10 \mathrm{~min}$, followed by layering the suspension over a $0.8 \%$ Methacel (Dow Chemical Co., Midland, Mich.)-50\% Hypaque (Winthrop Laboratories, New York, N.Y.) gradient and centrifuging at $650 \times g$ for $20 \mathrm{~min}$. The supernatant containing the treponemes was removed and used in all experiments unless otherwise stated.

Radiolabeling of T. pallidum. A $20-\mathrm{ml}$ volume containing $6 \times 10^{9}$ to $8 \times 10^{9}$ motile treponemes was incubated for $20 \mathrm{~h}$ at $34^{\circ} \mathrm{C}$ with $10 \mu \mathrm{Ci}$ of $\left[{ }^{35} \mathrm{~S}\right]$ methionine (specific activity, $950 \mathrm{Ci} / \mathrm{mmol}$; New England Nuclear Corp., Boston, Mass.) per ml under an air atmosphere (1). The organisms were then washed once in phosphate-buffered saline (PBS; $137 \mathrm{mM} \mathrm{NaCl}, 2.7$ $\mathrm{mM} \mathrm{KCl}$, $4.6 \mathrm{mM} \mathrm{Na} \mathrm{HPO}_{4}$, and $1.5 \mathrm{mM} \mathrm{KH}_{2} \mathrm{PO}_{4}$ ), pelleted, and stored at $-70^{\circ} \mathrm{C}$ until use.

Lactoperoxidase-catalyzed iodination of intact treponemes previously washed three times in PBS was performed by a modification of the procedure of Garvey et al. (16). Briefly, $5 \mu$ lof $\mathrm{Na}^{125} \mathrm{I}(0.5 \mathrm{mCi}$; New England Nuclear Corp.) and $100 \mu \mathrm{l}$ of lactoperoxidase (100 $\mu$ g; Calbiochem-Behring Corp., La Jolla, Calif.) were gently mixed with $0.5 \mathrm{ml}$ of PBS containing $8 \times$ $10^{9} \mathrm{~T}$. pallidum organisms. Then $50 \mu \mathrm{l}$ of $\mathrm{H}_{2} \mathrm{O}_{2}$ solution ( $5 \mu \mathrm{l}$ of $30 \%$ stock $\mathrm{H}_{2} \mathrm{O}_{2}$ freshly prepared in $125 \mathrm{ml}$ of PBS) was introduced, and incubation was continued for $15 \mathrm{~min}$. Another $50 \mu \mathrm{l}$ of $\mathrm{H}_{2} \mathrm{O}_{2}$ was added, and the reaction was allowed to proceed for another $15 \mathrm{~min}$. Iodinated organisms were then washed at least twice in PBI (1) to remove residual ${ }^{125}$ I, pelleted, and stored at $-70^{\circ} \mathrm{C}$. Processing for sodium dodecyl sulfate-polyacrylamide gel electrophoresis (SDS-PAGE) was done as previously published (1,3; Alderete and Baseman, submitted for publication).

High-salt and detergent treatment of intact $T$. pallidum. Between $1 \times 10^{10}$ and $2 \times 10^{10}$ freshly extracted and purified treponemes were pelleted by centrifugation at $17,500 \times g(15 \mathrm{~min})$ and suspended in $25 \mathrm{ml}$ of $200 \mathrm{mM}$ tris(hydroxymethyl)aminomethane (Tris)-hydrochloride buffer $(\mathrm{pH} 8.0)$ containing $1 \mathrm{M} \mathrm{NaCl}$. The suspension was then incubated in a rotary water bath shaker $(175 \mathrm{rpm})$ at $37^{\circ} \mathrm{C}$ for 60 min. The salt-treated treponemes were removed by centrifugation as described above, and unpelleted organisms in the supernatant were trapped by filtration through a $0.2-\mu \mathrm{m}$ filter. The filtrate containing salt- released material was dialyzed for 2 days against 4 liters of distilled, deionized water with daily changes. After dialysis, the material was lyophilized and either dissolved in PBS for application onto a Bio-Rad AffiGel (Bio-Rad Laboratories, Richmond, Calif.) column (1 by $10 \mathrm{~cm}$ ) for selective fractionation of treponemal proteins from contaminating host macromolecules (1, 44, 45) or suspended in appropriate buffer for SDSPAGE. The salt-extracted organisms were processed for gel electrophoresis by techniques previously described, employing $10 \%$ trichloroacetic acid precipitation of treponemal proteins $(1,19)$, or used for subsequent experimentation as outlined below.

Approximately $2 \times 10^{10}$ salt-treated treponemes, suspended in $30 \mathrm{mM}$ octyl glucoside (2; Sigma Chemical Co., St. Louis, Mo.) supplemented with $100 \mathrm{mM}$ Tris-hydrochloride ( $\mathrm{pH} 8.0$ ) containing $200 \mathrm{mM} \mathrm{NaCl}$, were vigorously blended on a Vortex mixer to cause selective detergent release of additional outer membrane proteins. The suspension was then centrifuged at $100,000 \times g$ for $60 \mathrm{~min}$, using a Dupont-Sorvall AH650 rotor. Both the supernatant and treponemal pellet were processed as described above for gel electrophoresis.

T. pallidum adherence to tissue cell monolayers. Human epithelial cells (HEp-2), kindly provided by Ed Hayes, Duke University, Durham, N.C., and primary cultures of normal rabbit testicular (NRT) cells established from normal, uninfected rabbits were seeded at a density of $5 \times 10^{4}$ and $1 \times 10^{5}$, respectively, into Leighton tubes containing a single cover slip (9 by $35 \mathrm{~mm}$ ) (17). Cultures were incubated overnight in Dulbecco-modified minimal essential medium (GIBCO, Grand Island, N.Y.) supplemented with $10 \%$ fetal bovine serum (GIBCO) in a $5 \% \mathrm{CO}_{2}$-air atmosphere at $37^{\circ} \mathrm{C}$. Just before coincubation with treponemes, the NRT cells were washed twice with PBS.

Approximately $3 \times 10^{8}$ motile freshly harvested treponemes clarified from host cellular contamination as described earlier (1) were treated with $1 \mathrm{mg}$ of trypsin (Sigma) per $\mathrm{ml}$ at $37^{\circ} \mathrm{C}$ for $60 \mathrm{~min}$, followed by centrifugation on a Methacel-Hypaque gradient. The suspension was then recentrifuged at $17,500 \times g$ for 10 min, and pelleted $T$. pallidum organisms were gently suspended in extraction medium containing $10 \%$ fetal bovine serum to a density of $3.5 \times 10^{7}$ per $\mathrm{ml}$ before addition to NRT cells for $2 \mathrm{~h}$. Control, non-trypsintreated treponemes were centrifuged similarly and coincubated for $2 \mathrm{~h}$ at $34^{\circ} \mathrm{C}$ before examination by dark-field microscopy (17).

Rabbit peritoneal macrophages were harvested 3 days after intraperitoneal injection of rabbits with 40 ml of sterile $12 \%$ vitamin-free casein hydrolysate $\mathbf{~} \mathrm{Nu}$ tritional Biochemical Corp., Cleveland, Ohio) (pH 8.0). About $10^{6}$ cells were seeded into Leighton tubes with cover slips and incubated overnight in Dulbecco-modified minimal essential medium supplemented with $20 \%$ fetal bovine serum under a $5 \% \mathrm{CO}_{2}$-air atmosphere at $37^{\circ} \mathrm{C}$. T. pallidum were then added, and the samples were processed as described above for treponemal adherence (17).

Test sera. Serum samples were obtained from infected rabbits at various times postinfection and handled as described elsewhere (Alderete and Baseman, 
submitted for publication). For antiserum against surface proteins, rabbits were immunized with specific preparations obtained by excision of individual protein bands from acrylamide gels after SDS-slab gel electrophoresis according to the method of Tjian et al. (44). Briefly, material from $5 \times 10^{10}$ treponemes was electrophoresed under denaturing conditions (1) using a 3-mm-thick $7.5 \%$ acrylamide separating gel. After staining and destaining, the bands corresponding to the proteins of interest were cut out and prepared for injection into individual rabbits (44). Subcutaneous and intramuscular injections of the mixture of protein, acrylamide, and Freund complete adjuvant (GIBCO) were followed by boosters at days 14 and 28 using an equivalent amount of treponemal material obtained as above except suspended in Freund incomplete adjuvant. All animals were bled before experimental infection or immunization with specific antigens, and the rabbits were examined for antibody by RIP.

RIP and SDS-PAGE. Frozen pellets of $4 \times 10^{9}$ $\left[{ }^{35}\right.$ S]methionine-labeled $T$. pallidum were solubilized in an SDS-Triton X-100 (Sigma) detergent system determined to be optimal for maximal solubilization of treponemal proteins (3). The extract was centrifuged at $150,000 \times g$ for $45 \mathrm{~min}$, followed by preadsorption with protein A-bearing Staphylococcus aureus to remove any nonspecific binding proteins. Volumes of $100 \mu$ l of the solubilized treponemal extract were then added to $20-\mu$ l volumes of various dilutions of antisera. After $2 \mathrm{~h}$ at $37^{\circ} \mathrm{C}, 50 \mu \mathrm{l}$ of $S$. aureus in NET $(150 \mathrm{mM}$ $\mathrm{NaCl}, 5 \mathrm{mM}$ ethylenediaminetetraacetic acid, $50 \mathrm{mM}$ Tris-hydrochloride, $\mathrm{pH}$ 7.2)-0.05\% Triton X-100 (3; Alderete and Baseman, submitted for publication) were added, and incubation was continued for $\mathbf{3 0} \mathrm{min}$ at $22^{\circ} \mathrm{C}$. The $S$. aureus-adsorbed immune complexes (18) were then sedimented and washed three times in NET-0.05\% Triton X-100 (3; Alderete and Baseman, submitted for publication). The immunoprecipitated, radiolabeled antigens were recovered by suspending the pellet in $70 \mu \mathrm{l}$ of dissolving buffer $(62.5 \mathrm{mM}$ Trishydrochloride, $\mathrm{pH} 6.8,2 \% \beta$-mercaptoethanol, $10 \%$ glycerol, $2 \%$ SDS, and $0.02 \%$ bromophenol blue) and boiling for $3 \mathrm{~min}$. The $S$. aureus cells were removed, and the supernatants were electrophoresed in a slab gel apparatus using $3 \%$ and $7.5 \%$ acrylamide for stacking and separating gels, respectively (3; Alderete and Baseman, submitted for publication). Slab gels were fixed and processed for fluorography as previously described (7). Formaldehyde-fixed $S$. aureus employed above were prepared as recently outlined (1; Alderete and Baseman, submitted for publication).

Cross-linking of surface proteins on intact treponemes. After $\left[{ }^{35} \mathrm{~S}\right]$ methionine labeling of $8 \times$ $10^{9}$ treponemes in $60 \mathrm{ml}$ of extraction medium, the organisms were washed once and suspended in $2.4 \mathrm{ml}$ of PBS. Volumes of $0.2 \mathrm{ml}$ were placed in sterile Corning Corex tubes and chilled to $4^{\circ} \mathrm{C}$. Then 0,10 , 25,50 , and $100 \mu \mathrm{g}$ of dithiobis(succinimidyl)propionate (DTSP; Pierce Chemical Co., Rockford, Ill.) freshly prepared in dimethyl sulfoxide were added to duplicate tubes, and the reaction was continued for $5 \mathrm{~min}$ at $4^{\circ} \mathrm{C}$. Upon termination of the reaction with an equal

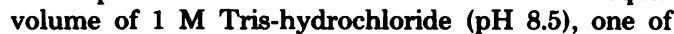
each duplicate received $\beta$-mercaptoethanol $(2 \%$ final concentration) before being incubated at $22^{\circ} \mathrm{C}$ for 15 min to cleave the cross-linker. Finally, each sample was processed for SDS-PAGE after $10 \%$ trichloroacetic acid precipitation by using dissolving buffer in the absence of any reducing agent, unless otherwise stated in the text.

\section{RESULTS}

Elucidation of $T$. pallidum surface proteins. $\left[{ }^{125}\right.$ I] lactoperoxidase-catalyzed iodination of intact, washed treponemes and SDS-PAGE were performed to characterize the surface proteins of $T$. pallidum. Figure 1B presents typical counts per minute patterns of $\left[{ }^{35} \mathrm{~S}\right]$ methioninelabeled treponemal proteins compared with the iodination profile of intact treponemes. When these gel patterns were aligned with the fluorogram (Fig. 1A), at least four areas, designated 1, 2,3 , and 4 , were heavily iodinated, corresponding to molecular weights of $89,500(89.5 \mathrm{~K}), 29.5 \mathrm{~K}$, $25.5 \mathrm{~K}$, and $20.0 \mathrm{~K}$, respectively. Two additional surface proteins, $5(59.0 \mathrm{~K})$ and $6(42.5 \mathrm{~K})$, were radioiodinated but to a lesser extent. The reproducibility and level of ${ }^{125} \mathrm{I}$ radiolabeling of protein 1 appeared to be related to the extensive handling of the freshly harvested treponemal populations. Repeated washings of treponemes adversely affected the efficient iodination of protein 1.

The more sensitive and highly specific radioimmunoprecipitation (RIP) technology was then employed to better resolve the total number of outer membrane proteins accessible to surface iodination. Convalescent rabbit syphilitic serum, known to have elevated levels of antitreponemal antibodies, reacted with all of the $\left[{ }^{35} \mathrm{~S}\right]$ methionine-labeled antigens solubilized in an SDS-Triton X-100 detergent system (Fig. 2 , gel A), and this pattern was identical to that of the total protein extract used. Reduced numbers of proteins, however, were detected by using the extract containing iodinated proteins (gel B). Normal rabbit serum did not immunoprecipitate ${ }^{35} \mathrm{~S}$ - or ${ }^{125} \mathrm{I}$-radiolabeled treponemal proteins. Of special interest was the enhanced resolution after iodination of surface proteins from the areas previously designated 2,3 , and 6 (Fig. 1). However, ${ }^{125}$ I-labeled protein 1 was not detected by RIP, suggesting its removal from the treponemal surface by the extensive washing required before and after radioiodination of intact organisms.

To clarify the orientation of protein 1 at the outer membrane, freshly harvested organisms were exposed to $1 \mathrm{M} \mathrm{NaCl}$, and analysis of the released material is presented in Fig. 3A. Gel a shows a typical Coomassie brilliant blue-stained profile of washed $T$. pallidum, whereas gel b shows the selective release of macromolecules from the treponemal surface by salt extraction. 

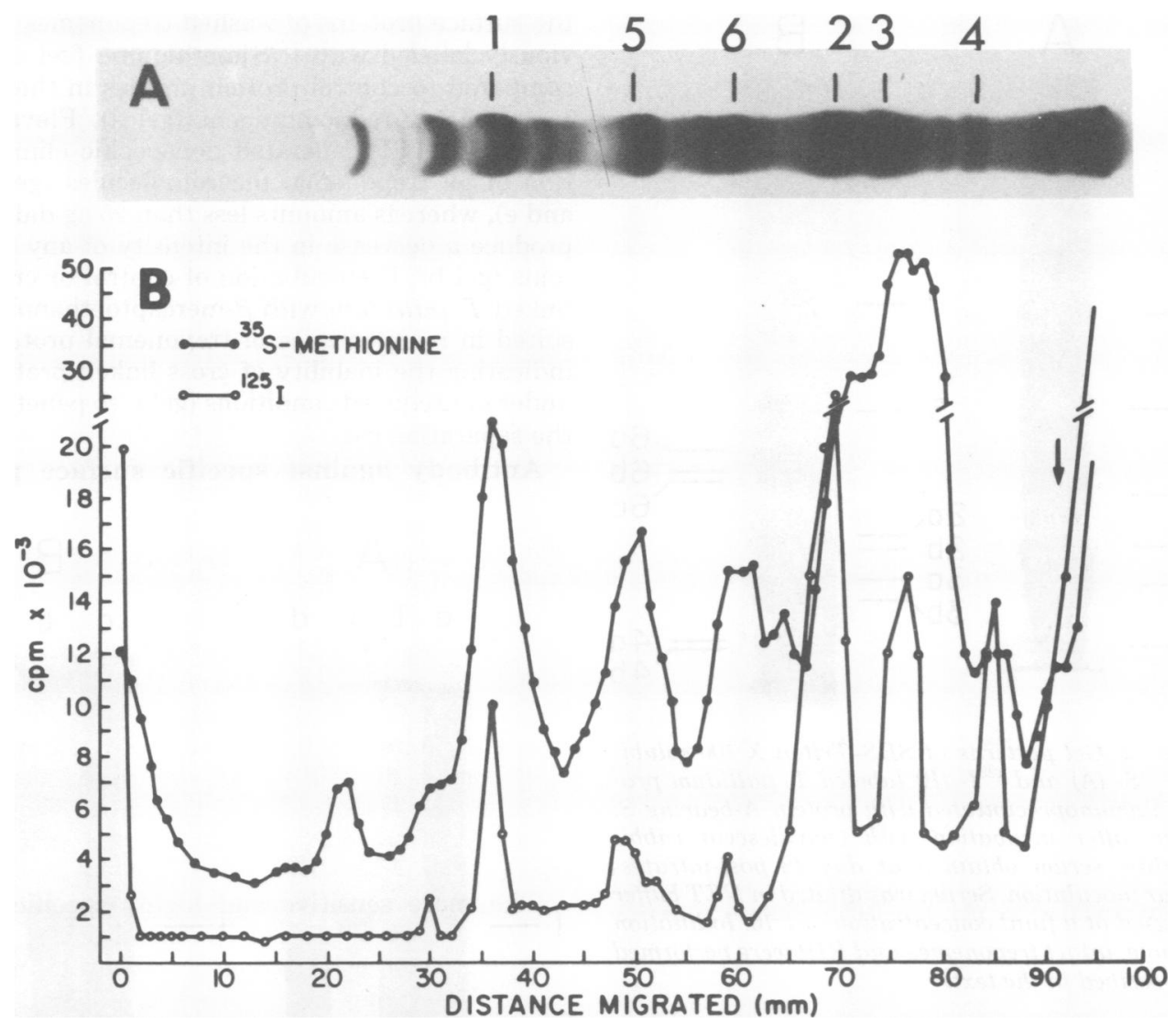

Fig. 1. Fluorogram (A) and corresponding counts per minute gel profile (B) of $\left[^{35} S\right]$ methionine-labeled treponemal proteins compared with a representative counts per minute gel pattern of $\left[^{125}\right.$ I]lactoperoxidaseiodinated treponemes after SDS-PAGE as described in the text. The numbers on the fluorogram represent the treponemal outer membrane proteins as detected through iodination.

Separation of protein 1 (gel c) from host material (gel d, 1) was accomplished through the fractionation of protein 1 from contaminating proteinaceous material by Bio-Rad Affi-Gel affinity chromatography $(45,47)$. The protein pattern of the salt-treated treponemes was similar to that seen for control, untreated organisms (gel a), indicating the presence of large amounts of additional protein 1 remaining after treatment. The absence of other treponemal protein bands in gel $b$ demonstrates the lack of treponemal lysis after $1 \mathrm{M} \mathrm{NaCl}$ exposure.

Because the orientation of protein 1 at the treponemal outer membrane appeared to include both salt-extractable and nonextractable locations, we attempted to release the remaining protein 1 via detergent treatment. Octyl glucoside, known to remove proteins sequestered via hydrophobic interactions (2), permitted extraction of proteins 2, 5, and 6 (Fig. 3B, gel c) from salt-treated organisms (gel a) without affecting protein 1. The removal of these proteins was consistent with the gel profile for glucoside-extracted organisms (Fig. 3B, gel b), revealing that protein 1 remained with the outer membranecell wall complex. Thus, the inability to promote release of additional protein 1 may suggest that these molecules remain sequestered within the outer membrane. To further analyze both the apparent surface and internal topography of protein 1 in relation to the outer envelope of $T$. pallidum, ${ }^{125}$ I-labeling of control versus salttreated treponemes was performed. As expected, little or no radioiodination of protein 1 was observed in salt-treated versus control treponemes (data not shown).

Antigenicity of the surface proteins. Once the proteins on the treponemal surface were identified, it was important to assess their antigenic nature. The presence of antibody against these proteins was monitored in the serum of intratesticularly infected rabbits (Alderete and 


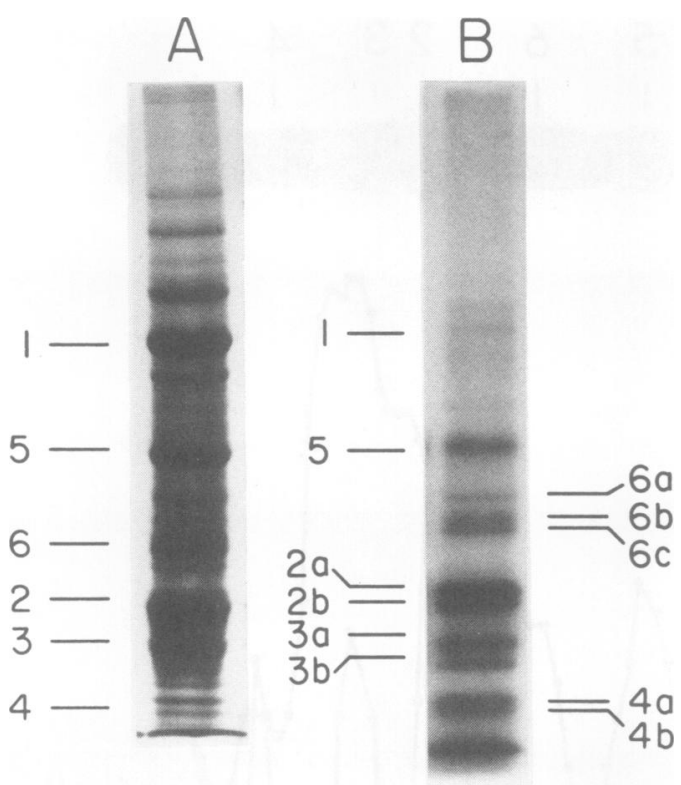

Fig. 2. Gel patterns of SDS-Triton X-100-solubilized ${ }^{35} S-(A)$ and ${ }^{125} I-(B)$ labeled $T$. pallidum proteins immunoprecipitated with protein A-bearing $S$. aureus after incubation with convalescent rabbit syphilitic serum obtained at day 48 post-intratesticular inoculation. Serum was diluted in NET buffer and used at a final concentration of 1:10. Iodination of whole, intact treponemes and RIP were performed as described in the text.

Baseman, submitted for publication). Antigenantibody complexes formed between $\left[{ }^{35}\right.$ S $]$ methionine-labeled treponemal proteins and rabbit serum obtained at days 10 and 48 postinfection were immunoprecipitated with $S$. aureus and examined by SDS-PAGE. Figure 4 clearly demonstrates that only antibodies against surface proteins were present early in infection (day 10), whereas the intensity of the fluorograms indicates that higher titers of antibody against these and other nonsurface treponemal proteins were detected with day-48-postinoculation serum. The profile obtained using day-48 syphilitic serum diluted 1:10 was identical to that of total solubilized treponemal proteins used in the RIP reaction mixture (data not shown).

Relationships between the outer membrane proteins. The intimate association of a tip structure on $T$. pallidum with host cell surfaces (17) and the evidence for proteins 1, 2, and 3 as putative ligands mediating the surface parasitism (3) led us to investigate the molecular organization of the outer membrane proteins by using a cleavable chemical cross-linker. Figure 5 (A and B) shows that only intermediate levels of DTSP, $25 \mu \mathrm{g}$, resulted in the cross-linking of the surface proteins of washed treponemes previously labeled with $\left[{ }^{35} \mathrm{~S}\right]$ methionine (gel c) as compared to control protein profiles in the absence of any reducing agent (gel a). Elevated levels of DTSP generated nonspecific elimination of all treponemal macromolecules (gels d and e), whereas amounts less than $25 \mu \mathrm{g}$ did not produce a decrease in the intensity of any proteins (gel b). Preincubation of control or crosslinked $T$. pallidum with $\beta$-mercaptoethanol resulted in reappearance of treponemal proteins, indicating the inability of cross-linked proteins under nonreduced conditions (gel f) to penetrate the separating gel.

Antibody against specific surface pro-

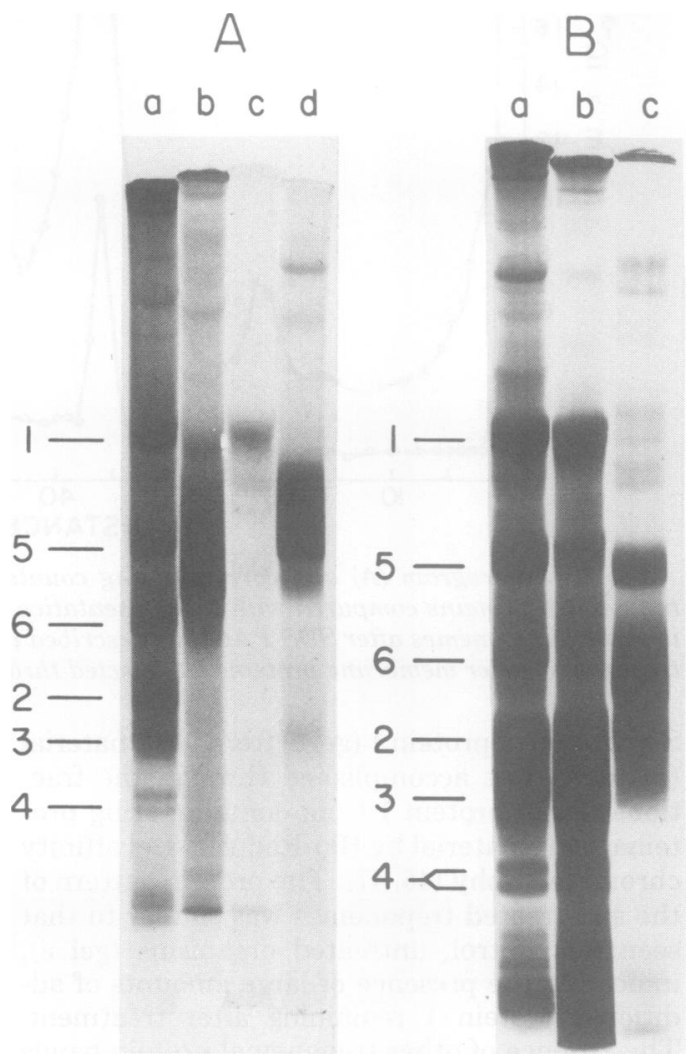

FIG. 3. SDS-PAGE analysis of specific treponemal surface proteins released by (A) high-salt (1 M NaCl) or (B) octyl glucoside detergent treatment of intact organisms. (A) Coomassie brilliant blue-stained proteins of (a) control treponemes, (b) material removed by salt extraction, (c) protein 1 purified by Bio-Rad Affi-Gel affinity chromatography, and (d) host proteins selectively adsorbed by the Affi-Gel affinity col-

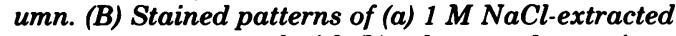
treponemes compared with (b) salt-treated organisms incubated with octyl glucoside. (c) Surface proteins liberated by detergent. 
teins. We decided to immunize rabbits with antigen-acrylamide preparations of proteins 1 or 2 and 3 to obtain specific antibody that could be used as probes to better understand the individual contributions of each ligand to host receptor binding (3). In Fig. 6, antisera raised against the

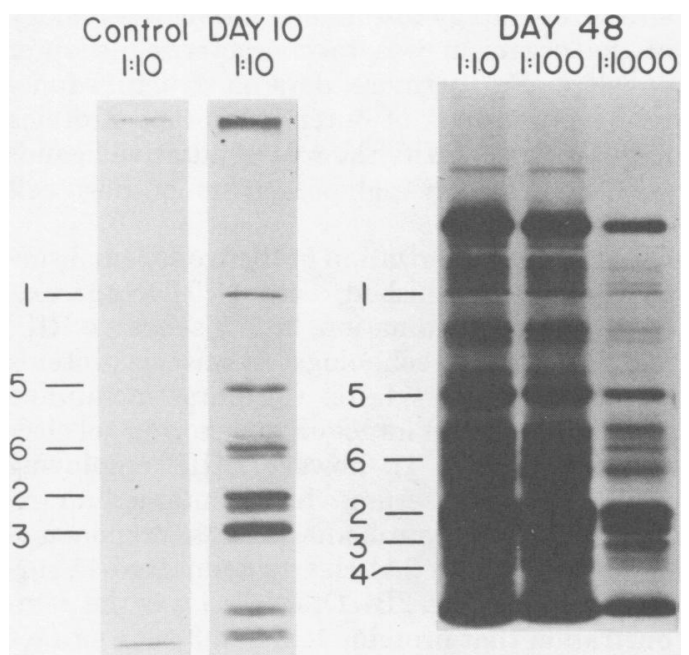

Fig. 4. Fluorogram of RIP using SDS-Triton $X$ 100 -solubilized ${ }^{35} S$-labeled treponemal proteins incubated with sera at two different times after intratesticular inoculation of a rabbit. The ratio above each gel pattern represents serum dilutions in NET buffer as described in the text. Control refers to normal rabbit serum obtained before infection.

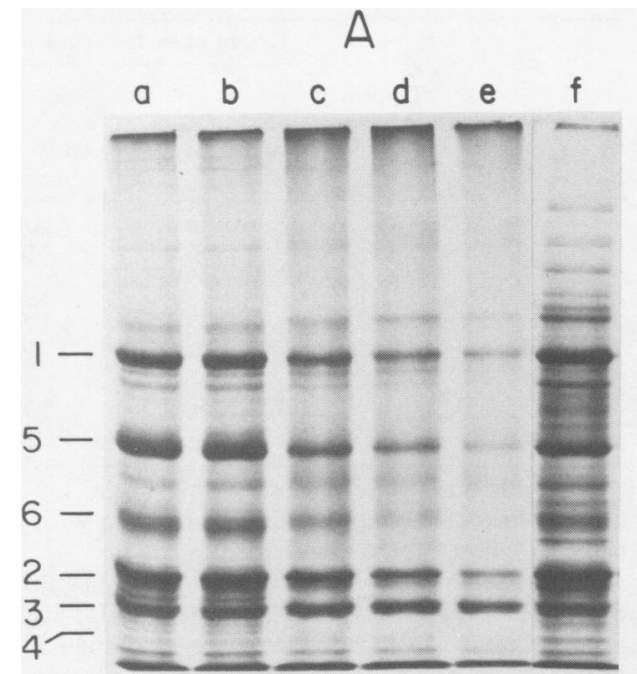

appropriate fractions are compared with control and convalescent rabbit syphilitic sera. As anticipated, RIP profiles using infected rabbit sera demonstrated an extensive humoral immune response to $T$. pallidum proteins (gels B and D). Unexpectedly, rabbits immunized with the acrylamide-protein mixtures comprised of either protein 1 alone or a combination of proteins 2 and 3 exhibited identical serological patterns when using radioiodinated treponemes (gel C) or $\left[{ }^{35} \mathrm{~S}\right]$ methionine-labeled proteins (gel E). These data dramatically revealed the antigenic relatedness of surface proteins 1 and $2 \mathrm{~b}$. No antibodies against proteins $2 \mathrm{a}, 3 \mathrm{a}$, and $3 \mathrm{~b}$ were detected with the immunization regimen employed in these studies.

Surface parasitism of eucaryotic cells by $T$. pallidum. Because trypsin digestion enhances the release of proteins 1 and 2 from the treponemal surface (1), we reasoned that protease treatment of motile, freshly harvested $T$. pallidum should adversely affect the extent of surface adherence, reinforcing the evidence that these ligands mediate attachment. Table 1 clearly shows that trypsinization of intact, freshly harvested motile organisms depressed the extent of treponemal parasitism per NRT cell as well as the total number of parasitized NRT cells.

To gain additional insight into possible ligandreceptor interactions, we attempted to support previous data $(3,5,17)$ implicating the role of specific molecules on eucaryotic cell surfaces as

Fig. 5. SDS-PAGE profiles of stained proteins (A) and equivalent fluorogram (B) of T. pallidum after cross-linking of surface proteins with (a) 0 , (b) 10, (c) 25, (d) 50, and (e) $100 \mu \mathrm{g}$ of DTSP as described in the text. (f) Cross-linked treponemes exposed to $\beta$-mercaptoethanol; note the reappearance of proteins which previously decreased in intensity after exposure to DTSP, as well as other proteins not seen in the absence of reducing agents. 


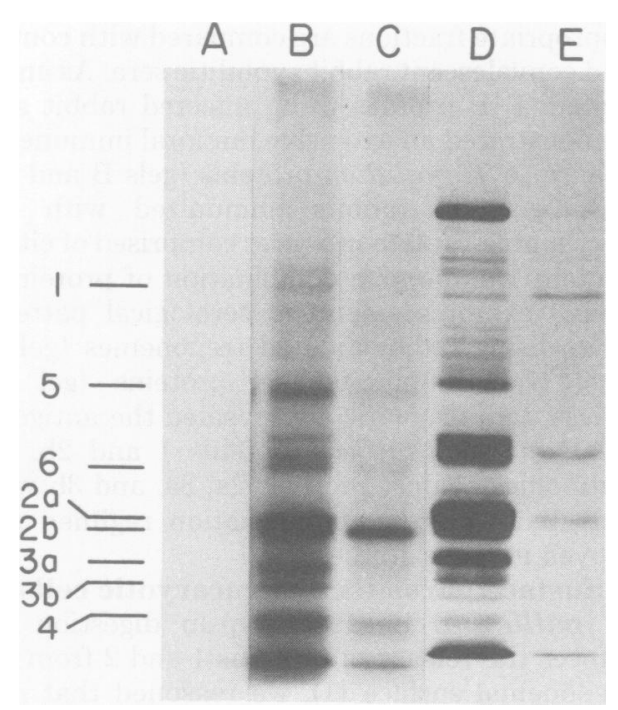

FIG. 6. RIP of immune complexes formed by incubation of SDS-Triton X-100-solubilized ${ }^{125} I-(B, C)$ or ${ }^{35} S-(D, E)$ labeled proteins with various sera as described in the text. Iodinated surface proteins and proteinaceous material radiolabeled with $\left[{ }^{35} \mathrm{~S}\right] \mathrm{me}$ thionine were immunoprecipitated with either convalescent rabbit syphilitic serum $(B, D)$ or antiserum raised against proteins 1 or 2 and $3(C, E)$. Normal rabbit serum obtained before infection or immunization was employed as the control and is represented in (A). All sera were diluted 1:10 in NET buffer.

mediators of the treponemal parasitism. Table 2 illustrates the attachment of $T$. pallidum to three eucaryotic cell types. NRT and HEp-2 cells and casein-elicited peritoneal macrophages briefly pretreated with periodate showed a decreased ability to accommodate treponemal attachment as compared with untreated cells. Periodate treatment was compatible with established procedures (36), and no loss of cell viability was detected by trypan blue exclusion. Phagocytosis of treponemes was not observed in either control or treated macrophages; however, the macrophages readily ingested large numbers of latex particles. These data suggest that specific carbohydrate-containing sites on eucaryotic cell membranes may mediate ligand binding.

\section{DISCUSSION}

$T$. pallidum, the causative agent of syphilis, is associated with a complex and unique host-parasite interaction. The different infectious stages have been well characterized and are related to disease progression and tissue cytopathology. Humoral as well as cellular immune mechanisms $(26,28,37,39,42,43,46$; Alderete and Baseman, submitted for publication) are known to be op- erative in the parasitized host, confirming the complicated nature of infection. However, little information is available concerning specific virulence determinants of $T$. pallidum. Since data have implicated the role of treponemal proteins in disease pathogenesis (3; Alderete and Baseman, submitted for publication), we felt that an effective strategy for understanding the biology of the organism was to characterize its outer envelope. Furthermore, data on structure-function relationships of outer membrane proteins might further clarify the role of putative ligands mediating treponemal parasitism of host cell surfaces $(3,5,17)$.

Initial characterization of the treponemal surface was accomplished using [ $\left.{ }^{125} \mathrm{I}\right]$ lactoperoxidase-catalyzed iodination, highly sensitive RIP, and SDS-PAGE technology. At least six proteins were found to reside on the outer membrane after iodination of intact organisms and gel electrophoresis (Fig. 1); however, RIP employing rabbit syphilitic serum which contained an extensive range of antibodies against treponemal components (Fig. 2A) clearly delineated 11 surface proteins (Fig. 2B). Of interest was the demonstration that proteins 1,2 , and 3 were surface located, consistent with an earlier report that these macromolecules were selectively bound to formaldehyde-fixed host cells (3). These data affirm their potential as ligands involved in adherence.

TABLE 1. Effect of trypsin treatment of motile $T$. pallidum on adherence to NRT cells

\begin{tabular}{|c|c|c|c|}
\hline \multirow[b]{2}{*}{ Expt } & \multirow[b]{2}{*}{$\begin{array}{c}\text { Trypsin } \\
\text { treatment }^{a}\end{array}$} & \multicolumn{2}{|c|}{ Extent of surface parasitism ${ }^{b}$} \\
\hline & & $\begin{array}{l}\text { No. of trepo- } \\
\text { nemes per cell }\end{array}$ & $\begin{array}{c}\% \text { of cells } \\
\text { with adher- } \\
\text { ent trepo- } \\
\text { nemes }\end{array}$ \\
\hline 1 & $\overline{+}$ & $\begin{array}{r}15 \pm 3 \\
3 \pm 2\end{array}$ & $\begin{array}{r}100 \\
10\end{array}$ \\
\hline 2 & + & $\begin{array}{r}22 \pm 4 \\
7 \pm 2\end{array}$ & $\begin{array}{r}100 \\
40\end{array}$ \\
\hline 3 & $\overline{+}$ & $\begin{array}{r}17 \pm 3 \\
6 \pm 1\end{array}$ & $\begin{array}{r}100 \\
47\end{array}$ \\
\hline
\end{tabular}

a Treponemes were treated with trypsin for $1 \mathrm{~h}$ at $37^{\circ} \mathrm{C}$ before centrifugation and incubation with NRT cells for $2 \mathrm{~h}$ at $34^{\circ} \mathrm{C}$ as described in the text.

${ }^{b}$ The Leighton tube cover slips were scanned by dark-field microscopy, and numerous NRT cells of approximately the same size were examined for the presence or absence of adherent treponemes. The degree of parasitism is expressed as the average number of treponemes attached to individual cells on duplicate monolayer cultures. All attached treponemes remained motile throughout the duration of the experiment. 
TABLE 2. Effect of periodate treatment of eucaryotic cells on adherence by $T$. pallidum

\begin{tabular}{|c|c|c|c|c|}
\hline \multirow[b]{2}{*}{ Cell type ${ }^{a}$} & \multirow[b]{2}{*}{ Expt } & \multirow[b]{2}{*}{$\begin{array}{c}10 \\
\text { mM } \\
\text { perio- } \\
\text { date } \\
\text { treat- } \\
\text { ment }^{b}\end{array}$} & \multicolumn{2}{|c|}{$\begin{array}{l}\text { Extent of surface } \\
\text { parasitism }\end{array}$} \\
\hline & & & $\begin{array}{c}\text { No. of } \\
\text { trepo- } \\
\text { nemes per } \\
\text { cell }\end{array}$ & $\begin{array}{l}\% \text { of } \\
\text { cells } \\
\text { with } \\
\text { adher- } \\
\text { ent } \\
\text { trepo- } \\
\text { nemes }\end{array}$ \\
\hline NRT cells & $\begin{array}{l}1 \\
2\end{array}$ & $\begin{array}{l}- \\
+ \\
- \\
+\end{array}$ & $\begin{aligned} 21 & \pm 3 \\
5 & \pm 2 \\
20 & \pm 4 \\
2 & \pm 1\end{aligned}$ & $\begin{array}{r}100 \\
35 \\
100 \\
5\end{array}$ \\
\hline HEp-2 cells & 2 & $\begin{array}{l}- \\
+ \\
- \\
+\end{array}$ & $\begin{array}{l}7 \pm 1 \\
2 \pm 1 \\
7 \pm 1 \\
2 \pm 1\end{array}$ & $\begin{array}{r}100 \\
50 \\
100 \\
10\end{array}$ \\
\hline $\begin{array}{l}\text { Rabbit peritoneal } \\
\text { macrophages }\end{array}$ & $\begin{array}{l}1 \\
2\end{array}$ & $\begin{array}{l}- \\
+ \\
+ \\
+\end{array}$ & $\begin{array}{r}8 \pm 1 \\
4 \pm 1 \\
10 \pm 3 \\
3 \pm 2\end{array}$ & $\begin{array}{r}100 \\
50 \\
100 \\
57\end{array}$ \\
\hline
\end{tabular}

${ }^{a}$ Cells were cultured and seeded onto Leighton tube cover slips as described in the text.

${ }^{b}$ Periodate treatment was performed in Leighton tubes on washed cells at $22^{\circ} \mathrm{C}$ for $10 \mathrm{~min}$, followed by extensive washing with PBS. Motile, freshly harvested $T$. pallidum organisms were then added as described in the text.

' As described in Table 1.

The selective release of only low levels of proteins 1 and 2 by salt treatment or octyl glucoside extraction, respectively, demonstrates the unique surface orientation of these implicated proteins. Released protein 1 was shown to be identical to the remaining comigrating treponemal protein, which was not radioiodinated (Fig. 3A). Antibodies prepared against purified protein 1 (Fig. 3A, gel c) immunoprecipitated ${ }^{35}$ S]methionine-labeled protein 1 not liberated by high salt levels (Alderete and Baseman, unpublished data). The accumulation of substantial amounts of protein 1 possibly internalized within the outer envelope-cell wall complex may reflect a mechanism for the rapid generation and replacement of this molecule that may be readily shed during infection. The possibility exists that liberation of a large-molecular-weight molecule such as protein 1 may have adverse consequences for the parasitized host. Its highly immunogenic character (Fig. 4) may result in immune complexes $(34,38)$ which are deposited in tissue, resulting in cytopathology. Additionally, such soluble immune complexes may accumulate in infected individuals and influence cellular immune mechanisms (46). Furthermore, the binding of released protein 1 to the membranes of cells as described by Baseman and Hayes (3) might cause prolonged antigenic stimulation as well as autoimmune reactions resulting from altered or unique parasite-host, protein-protein interactions. Finally, loss of protein 1 during extended suboptimal in vitro incubations may result in the inability of the treponemes to parasitize cells (17). In this case, such altered treponemes may be unable to regenerate functional ligand from an internalized pool, suggesting deficiencies in treponemal metabolism.

The presence of a tip structure on $T$. pallidum associated with treponemal attachment to host cell surfaces (17) and the identification of proteins 1 and 2 as putative ligands (3) reinforced the need to dissect and characterize the molecular organization of the outer membrane proteins. Attempts to demonstrate selective multicomponent interactions between specific treponemal surface molecules with a cleavable crosslinker were unsuccessful under the conditions employed. The reappearance of cross-linked products removed by DTSP after exposure to $\beta$-mercaptoethanol, however, suggests that highmolecular-weight aggregates were formed which could not penetrate the acrylamide gels. Thus, stoichiometric removal of all outer envelope proteins after addition of reagent (Fig. 5) suggests a highly fluid membrane resulting in random collisions and formation of large-molecularweight products $(6,9,24,27,31)$. Since the protocol employed in this study is consistent with that utilized for other bacterial systems (27, 40), these data may indicate a highly complex treponemal surface requiring more sensitive probes and alternative experimental conditions $(24,31)$ for clarification of the protein organization.

The observation of antigenic relatedness between proteins 1 and $2 b$ is noteworthy but not clearly understood (Fig. 6). Since both have been identified as potential ligands (3), there is a possibility of each possessing identical "active sites" involved in host cell receptor recognition. Also, a precursor-product relationship may exist between these molecules. An alternate explanation is that $T$. pallidum expresses a nonfunctional protein antigenically similar to the biologically important molecule(s), which could then be spared during immune surveillance. This would allow the organism to disseminate and establish residence through surface parasitism of other tissues. The relationship between proteins 1 or $2 \mathrm{~b}$ and the $40 \mathrm{~K}$ protein, which is also immunoprecipitated during incubation of soluble $\left[{ }^{35} \mathrm{~S}\right]$ methionine-labeled $T$. pallidum preparations with specific antisera (Fig. $6 \mathrm{E}$ ) to pro- 
teins 1 or $2 b$, is unknown and requires further experimentation. It may represent an internalized precursor to $2 \mathrm{~b}$ which is not detectable when using radioiodinated treponemes (Fig. 6C).

The role of outer envelope proteins as ligands mediating cell surface parasitism was reinforced by the adverse effect on treponemal attachment to NRT cells upon trypsin digestion of intact, motile $T$. pallidum (Table 1). These data indicated a proteinaceous nature for these functional surface molecules. We have previously demonstrated the release of proteins 1 and 2 from intact organisms by trypsin treatment (1) and now suggest that this chemical alteration is largely responsible for the reduced parasitism to NRT cells. The relationship of these putative ligands to the observations of Fitzgerald and Johnson (13) is presently unknown.

Finally, brief periodate exposure of NRT and HEp-2 cells and casein-elicited peritoneal macrophages produced significantly decreased surface parasitism by $T$. pallidum of each cell type as compared to nontreated control cells (Table 2 ). These observations not only support the recent data of Baseman and Hayes (3) describing the interaction of treponemal surface proteins with trypsin-sensitive receptors on host membranes, but correlate with the presence of carbohydrate-containing membrane structures on eucaryotic cells which accommodate bacterial surface ligands $(10,36)$. Alternately, gross modification of acidic carbohydrate residues on the cell surface may have affected physical parameters such as charge distribution which may diminish treponemal ligand attachment.

The surface characterization of highly antigenic molecules of $T$. pallidum involved in mediating attachment to host cells permits numerous applications. The demonstration of high titers of antibody in infected rabbits (Alderete and Baseman, submitted for publication) and syphilitic humans (3; Alderete and Baseman, submitted for publication) against these surface proteins (Fig. 4) supports their immunogenic potential and consideration as multicomponent vaccine candidates. Also, this information might allow for the development of a more sensitive, rapid, and accurate serological diagnostic test which not only enables efficient surveillance of the population but also permits identification of the stage of infection. In support of this, approximately 300-day-postinfection sera from intradermally and intratesticularly infected rabbits immunoprecipitated primarily only protein 2 (Alderete and Baseman, unpublished data), suggesting that levels of this antigen may correlate with the progression of disease. Also, these surface immunogens might be employed to discrim- inate among virulent treponemal strains or species through development of serological typing $(29,30)$. Finally, the detection of the putative ligands (3) on the treponemal surface should permit the employment of recombinant deoxyribonucleic acid technology as a vehicle for synthesizing these specific, highly antigenic proteins. Thus the need for in vitro cultivation of the organisms would be circumvented, and sufficient amounts of specific treponemal proteins would be available for targeted studies as outlined above.

\section{ACKNOWLEDGMENTS}

This work was supported by Public Health Service grant AI-15036 and research career development award 1-K04-AI00178 from the National Institute of Allergy and Infectious Diseases to J.B.B.

\section{LTERATURE CITED}

1. Alderete, J. F., and J. B. Baseman. 1979. Surfaceassociated host proteins on virulent Treponema pallidum. Infect. Immun. 26:1048-1056.

2. Baron, C., and T. E. Thompson. 1975. Solubilization of bacterial membrane proteins using alkyl glucosides and dioctanyl phosphatidylcholine. Biochem. Biophys. Acta 382:276-285.

3. Baseman, J. B., and E. C. Hayes. 1980. Molecular characterization of receptor binding proteins and immunogens of virulent Treponema pallidum. J. Exp. Med. 151:573-586.

4. Baseman, J. B., and N. S. Hayes. 1974. Protein synthesis by Treponema pallidum extracted from infected rabbit tissue. Infect. Immun. 10:1350-1355.

5. Baseman, J. B., N. S. Hayes, J. K. Spitznagel, and E. C. Hayes. 1979. Virulence determinants among the spirochetes, p. 203-208. In D. Schlessinger (ed.), Microbiology-1979. American Society for Microbiology, Washington, D.C.

6. Berg, H. C., and E. M. Purcell. 1977. Physics of chemoreception. Biophys. J. 20:193-219.

7. Bonner, W. M., and R. A. Laskey. 1974. A film detection method for tritium-labeled proteins and nucleic acids in polyacrylamide gels. Eur. J. Biochem. 46:83-88.

8. Brause, B. D., and R. B. Roberts. 1978. Attachment of virulent Treponema pallidum to human mononuclear phagocytes. Br. J. Vener. Dis. 54:218-224.

9. Chi-Kuang, H., and F. M. Richards. 1977. Reaction of a lipid-soluble, unsymmetrical, cleavable crosslinking reagent with muscle aldolase and erythrocyte membrane proteins. J. Biol. Chem. 252:7413-7416.

10. Eshdat, Y., I. Ofek, Y. Yashour-Gan, N. Sharon, and D. Mirelman. 1978. Isolation of a mannose-specific lectin from Escherichia coli and its role in the adherence of the bacteria to epithelial cells. Biochem. Biophys. Res. Commun. 85:1551-1559.

11. Fieldsteel, A. H., F. A. Becker, and J. G. Stout. 1977 Prolonged survival of virulent Treponema pallidum (Nichols strains) in cell-free and tissue culture systems. Infect. Immun. 18:173-182.

12. Fieldsteel, A. H., J. G. Stout, and F. A. Becker. 1979. Comparative behavior of virulent strains of Treponema pallidum and Treponema pertenue in gradient cultures of various mammalian cells. Infect. Immun. 24:337-345.

13. Fitzgerald, T. J., and R. C. Johnson. 1979. Mucopoly saccharidase of Treponema pallidum. Infect. Immun. 24:261-268.

14. Fitzgerald, T. J., R. C. Johnson, J. N. Miller, and J. 
A. Sykes. 1977. Characterization of the attachment of Treponema pallidum (Nichols strain) to cultured mammalian cells and the potential relationship of attachment to pathogenicity. Infect. Immun. 18:467-478.

15. Garten, W., I. Hindennach, and U. Henning. 1975. The major proteins of the Escherichia coli outer cell envelope membrane. Eur. J. Biochem. 59:215-221.

16. Garvey, J. S., N. E. Cremer, and D. H. Sussdorf. 1977. ${ }^{125}$ I or ${ }^{131}$ I-labeled proteins, p. 171-182. In D. H. Campbell (ed.), Methods in immunology. W. A. Benjamin, Inc., Reading, Mass.

17. Hayes, N. S., K. E. Muse, A. M. Collier, and J. B. Baseman. 1977. Parasitism by virulent Treponema pallidum of host cell surfaces. Infect. Immun. 17:174186.

18. Hjelm, H., K. Hjelm, and J. Sjoquist. 1972. Protein A from Staphylococcus aureus. Its isolation by affinity chromatography and its use as an immunosorbent for isolation of immunoglobulins. FEBS Lett. 28:73-76.

19. Hu, P. C., A. M. Collier, and J. B. Baseman. 1977 Surface parasitism by Mycoplasma pneumonia of respiratory epithelium. J. Exp. Med. 145:1328-1343.

20. Johnson, R. C., D. M. Ritzi, and B. P. Livermore. 1973. Outer envelope of virulent Treponema pallidum. Infect. Immun. 8:291-295.

21. Johnson, R. C., M. S. Wachter, and D. M. Ritzi. 1973 Treponeme outer cell envelope: solubilization and reaggregation. Infect. Immun. 7:249-258.

22. Johnston, K. H., and E. C. Gotschlick. 1974. Isolation and characterization of the outer membrane proteins of Neisseria gonorrhoeae. J. Bacteriol. 119:250-257.

23. Jones, R. H., M. A. Finn, J. J. Thomas, and C. Folger. 1976. Growth and subculture of pathogenic $T$. pallidum (Nichols strain) in BHK-21 cultured tissue cells. Br. J. Vener. Dis. 52:18-23.

24. Kiehm, D. J., and T. H. Ji. 1977. Photochemical crosslinking of cell membrane. J. Biol. Chem. 252:8524-8531.

25. King, G. J., and J. Swanson. 1978. Studies on gonococcus infection. XV. Identification of surface proteins of Neisseria gonorrhoeae correlated with leukocyte association. Infect. Immun. 21:575-584.

26. Klein, J. R., A. A. Monjan, P. H. Hardy, Jr., and G. A. Cole. 1980. Abrogation of genetically controlled resistance of mice to Treponema pallidum by irradiation. Nature (London) 283:572-574.

27. Lomant, A. J., and G. Fairbanks. 1976. Chemical probes of extended biological structures: synthesis and properties of the cleavable protein cross-linking reagent [ ${ }^{35}$ S]dithiobis(succinimidyl propionate). J. Mol. Biol. 104:243-261.

28. Maret, S. M., J. B. Baseman, and J. D. Folds. 1980. Cell-mediated immunity in Treponema pallidum-infected rabbits: in vitro response of spleens and lymphocytes to mitogens and specific antigen. Clin. Exp. Immunol. 39:38-43.

29. McDade, R. L., Jr., and K. H. Johnston. 1980. Characterization of serologically dominant outer membrane proteins of Neisseria gonorrhoeae. J. Bacteriol. 141: 1183-1191.

30. Miao, R. M., and A. H. Fieldsteel. 1980. Genetic relationship between Treponema pallidum and Treponema pertenue, two noncultivable human pathogens. J. Bacteriol. 141:427-429.

31. Mikkelsen, R. B., and D. F. H. Wallach. 1976. Photoactivated cross-linking of proteins within the erythrocyte membrane core. J. Biol. Chem. 251:7413-7416.

32. Mitchell, G. F. 1979. Responses to infection with metazoan and protozoan parasites in mice. Adv. Immunol. 28:451-511.

33. Moll, A., P. A. Manning, and K. N. Timmis. 1980 . Plasmid-determined resistance to serum bactericidal activity: a major outer membrane protein, the traT gene product, is responsible for plasmid-specified serum resistance in Escherichia coli. Infect. Immun. 28:359367.

34. Mustakallio, K. K., A. Lassus, and O. Wager. 1977. Autoimmune phenomena in syphilitic infection: rheumatoid factor and cryoglobulins in different stages of syphilis. Int. Arch. Allergy 31:417-426.

35. Nell, E. E., and P. H. Hardy. 1972. The use of freezepreserved treponemes in the Treponema pallidum immobilization test. Cryoglobulin 9:404-410.

36. Ofek, I., D. Mirelman, and N. Sharon. 1977. Adherence of Escherichia coli to human mucosal cells mediated by mannose receptors. Nature (London) 265:623-625.

37. Pavia, C. S., J. D. Folds, and J. B. Baseman. 1977. Cell-mediated immunity during syphilis. Br. J. Vener. Dis. 54:144-150.

38. Peltier, A., and C. L. Christian. 1959. The presence of the "rheumatoid factor" in sera from patients with syphilis and rheumatism. Arthritis Rheum. 11:1-7.

39. Perine, P. L., R. S. Weiser, and S. J. Klebanoff. 1973. Immunity to syphilis: passive transfer in rabbits with hyperimmune serum. Infect. Immun. 8:787-790.

40. Reithmeier, R. A. F., and P. D. Bragg. 1977. Crosslinking of the proteins in the outer membrane of Escherichia coli. Biochem. Biophys. Acta 466:245-256.

41. Sandok, P. L., H. M. Jenkin, H. M. Matthews, and M. S. Roberts. 1978. Unsustained multiplication of Treponema pallidum (Nichols virulent strain) in vitro in the presence of oxygen. Infect. Immun. 19:421-429.

42. Schell, R. F., J. K. Chan, and J. L. LeFrock. 1979 Endemic syphilis: passive transfer of resistance with serum and cells in hamsters. J. Infect. Dis. 140:378-384

43. Titus, R. G., and R. S. Weiser. 1979. Experimental syphilis in the rabbit. Passive transfer with immunoglobulin G from immune serum. J. Infect. Dis. 140:904913.

44. Tjian, R., D. Stinchcomb, and R. Losick. 1974. Antibody directed against Bacillus subtilus $\sigma$ factor purified by sodium dodecyl sulfate gel electrophoresis. J. Biol Chem. 22:8824-8828.

45. Travis, J., and R. Pannell. 1973. Selective removal of albumin from the plasma by affinity chromatography. Clin. Chim. Acta 49:49-52.

46. Ware, J. L., J. D. Folds, and J. B. Baseman. 1979. Serum of rabbits infected with Treponema pallidum (Nichols) inhibits in vitro transformation of normal rabbit lymphocytes. Cell Immunol. 42:363-372.

47. Wille, L. E. 1976. A simple and rapid method for isolation of serum lipoproteins from the other serum protein constituents. Clin. Chim. Acta 71:355-357. 